\title{
The role of microbes in snowmelt and radiative forcing on an Alaskan icefield
}

\author{
Gerard Q. Ganey ${ }^{1}$, Michael G. Loso ${ }^{1,2}$, Annie Bryant Burgess ${ }^{3}$ and Roman J. Dial ${ }^{1 \star}$
}

\begin{abstract}
A lack of liquid water limits life on glaciers worldwide but specialized microbes still colonize these environments. These microbes reduce surface albedo, which, in turn, could lead to warming and enhanced glacier melt. Here we present results from a replicated, controlled field experiment to quantify the impact of microbes on snowmelt in red-snow communities. Addition of nitrogen-phosphorous-potassium fertilizer increased alga cell counts nearly fourfold, to levels similar to nitrogen-phosphorusenriched lakes; water alone increased counts by half. The manipulated alga abundance explained a third of the observed variability in snowmelt. Using a normalized-difference spectral index we estimated alga abundance from satellite imagery and calculated microbial contribution to snowmelt on an icefield of $1,900 \mathrm{~km}^{2}$. The red-snow area extended over about $700 \mathrm{~km}^{2}$, and in this area we determined that microbial communities were responsible for $17 \%$ of the total snowmelt there. Our results support hypotheses that snow-dwelling microbes increase glacier melt directly in a bio-geophysical feedback by lowering albedo and indirectly by exposing low-albedo glacier ice. Radiative forcing due to perennial populations of microbes may match that of non-living particulates at high latitudes. Their contribution to climate warming is likely to grow with increased melt and nutrient input.
\end{abstract}

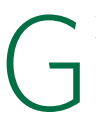
lacier ablation is sensitive to changes in albedo $^{1}$, with atmospheric $^{2,3}$, hydrological ${ }^{4}$ and ecological ${ }^{5,6}$ consequences. Fresh snow reflects $>90 \%$ of visible radiation, but during melt its grain size and water content increase, reducing albedo and further increasing snowmelt ${ }^{1}$. Impurities, including black carbon ${ }^{3}$, dust $^{4}$, and resident microbes ${ }^{7-19}$, also lower albedo; however, microbes differ from non-living particulates in several critical ways. Perennial populations of photosynthetic microbes actively resurface following overwinter burial by snow ${ }^{20}$, and depend on liquid water and nutrients for survival and reproduction ${ }^{13,14,20-22}$. This requirement for liquid water in a frozen environment imposes a selective force favouring a physiology that increases melt proximal to cell walls. The generation of meltwater through microbes' albedoreducing properties motivates an hypothesis of bio-geophysical feedback on glacial landscapes ${ }^{13,16}$, such as the Greenland ice sheet. This feedback hypothesis, whereby microbes increase because they produce needed meltwater, is an active research area ${ }^{13-19}$, yet field experiments testing its assumptions are absent.

Glacier microbiomes are water-limited ${ }^{21,22}$, because ice is generally not metabolically available, and oligotrophic, because their nutrient content equals that of precipitation plus deposition by airborne dust, pollen, and so on, with only limited $\mathrm{N}$-fixation by local cyanobacteria ${ }^{21,22}$. Moreover, rapidly percolating water through large-grained snow may exacerbate both water- and nutrient limitation for algae in supraglacial snow-covered habitat ${ }^{7}$. Surface meltwater on glaciers derives principally from radiative flux into the snowpack ${ }^{2}$, with the spectral distribution of albedo determining absorbed insolation ${ }^{1,3}$. Thus, snow algae increase liquid water availability through 'bioalbedo ${ }^{\text {'18 }}$, determined by the absorptive properties of their photosynthetic and secondary pigments. The chlorophylls and carotenoids in red-snow algae-particularly the heat-dissipating tetraterpenoid astaxanthin that colours cells red as protection from excess radiation ${ }^{23,24}$-reduce snow-surface albedo in the visible spectrum. Nutrient depletion in the snowpack triggers production of carotenoids ${ }^{20}$ in non-motile cells that ultimately overwinter as buried cysts. Spring meltwater then stimulates germination when propagules actively disperse through the snowpack, absorbing nutrients, photosynthesizing, and reproducing there and at the surface ${ }^{20}$.

This study experimentally demonstrates the potent role of redsnow algae in glacier melt. It presents novel results that establish these algae as both nutrient- and water-limited, and shows redsnow algae satisfy two assumptions of a bio-geophysical feedback loop for snowmelt. By manipulating alga abundance and simultaneously measuring melt on an icefield's surface, a causal, quantitative 'alga-melt model' is provided. Simultaneous field measures of spectral reflectance and alga abundance motivate a normalizeddifference snow-darkening index (NDI) to estimate alga abundance through remote sensing. Instantaneous radiative forcing (IRF) is calculated as a function of alga abundance using abundance-specific reflectance spectra integrated with instantaneous irradiance. Spatially mapping red-snow algae with satellite-derived NDI, together with the alga-IRF and alga-melt models, allows estimation of the red-snow ecosystem's contribution to snowmelt on Alaska's Harding Icefield $\left(60^{\circ} \mathrm{N}, 150^{\circ} \mathrm{W}\right.$; Supplementary Fig. 1). Adjacent to the Gulf of Alaska, this rapidly thinning ${ }^{25}$ network of $>30$ glaciers covers $1,890 \mathrm{~km}^{2}$ and drains a snow- and ice-covered plateau, providing a potential model for ice sheets in Greenland and Antarctica.

Interval photography (Supplementary Movie) and an automated weather station on the Eklutna Glacier $\left(61.21^{\circ} \mathrm{N} 148.96^{\circ} \mathrm{W}\right.$; Supplementary Fig. 1) demonstrated previous observations ${ }^{16-24}$ that the appearance of red snow coincides with increased melt rate and temporal trends in melt predictors (Fig. 1a). A PCA rotation of melt predictors showed that the first principal component (PC1) explained $89 \%$ of overall variance in melt predictors and $31 \%$ of the variability in daily melt rate (Fig. $1 \mathrm{~b}, n=94$ days). Prior to the appearance of red snow, PC1 showed no temporal trend, but then increased sharply with red snow. The temporal correspondence of

${ }^{1}$ Department of Environmental Science, Alaska Pacific University, Anchorage, Alaska 99508, USA. ${ }^{2}$ National Park Service, Wrangell-St. Elias National Park and Preserve, Copper Center, Alaska 99573, USA. ${ }^{3}$ Earth Science Information Partners, Boulder, Colorado 80304, USA. *e-mail: roman@alaskapacific.edu 
a PC1 by date

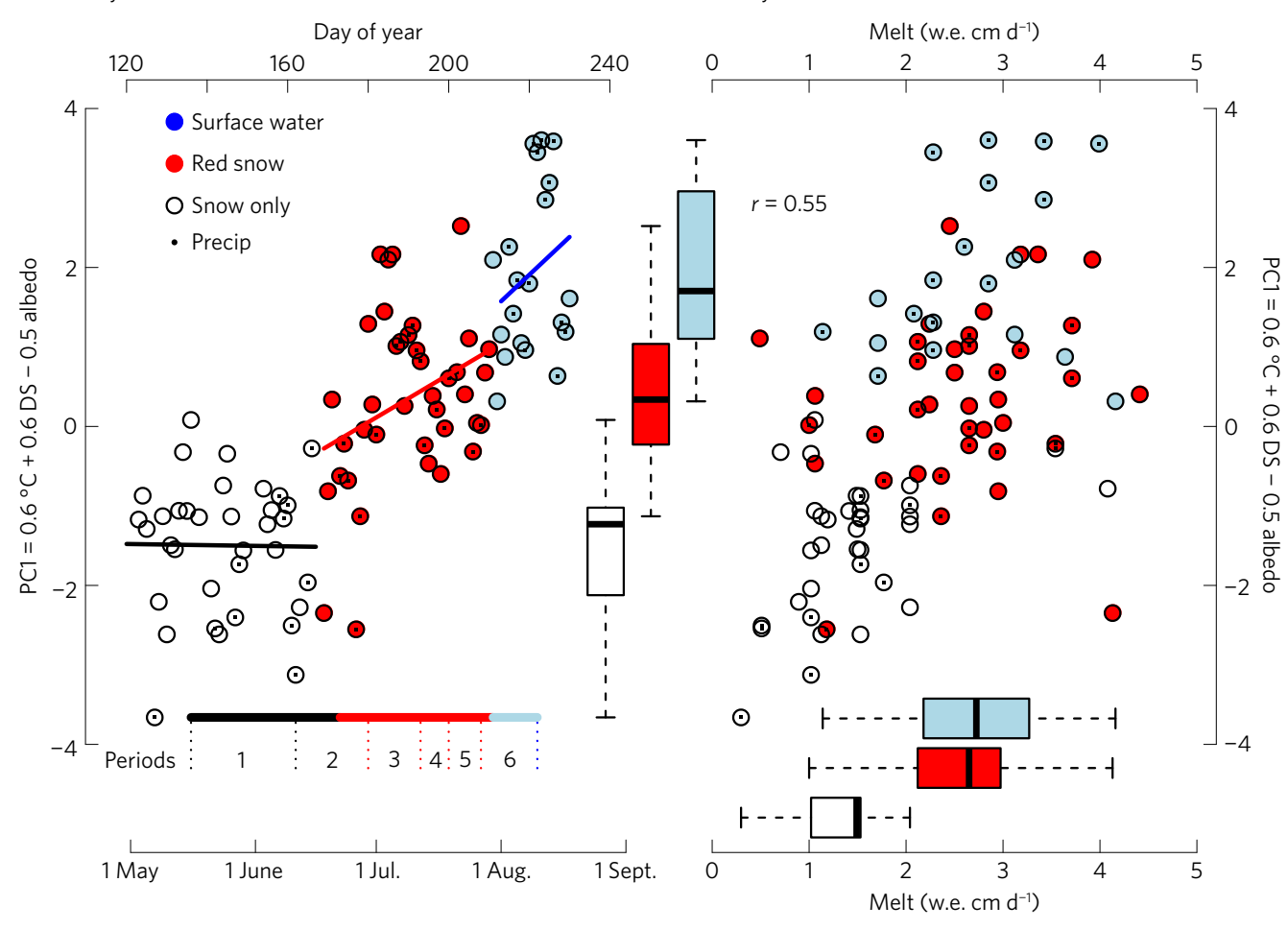

Figure 1 | Appearance of red snow coincides with melt predictors on Eklutna Glacier, 2014. a, Daily values for first principal component (PC1) of melt predictors: temperature at $2 \mathrm{~m}\left({ }^{\circ} \mathrm{C}\right)$, thawing degree-day sum (DS), and albedo. Colours indicate sub-seasons from hourly interval photography. Trend lines give linear regression over each sub-season. Coloured horizontal bar indicates dates of sub-seasons on Harding Icefield, 2014. b, Relationship between daily values of $\mathrm{PC} 1$ and snowmelt with Pearson correlation. Box plots show distributions of PC1 and melt rate by sub-season.

red snow, melt predictors, and melt rate are consistent with red-snow algae acting as both a cause and an effect of snowmelt. We focus here on the red-snow sub-season, when snow algae are most likely involved in snowmelt.

\section{Nutrients and water limit snow-alga abundance}

Experimental additions of an aqueous solution of nitrogenphosphorus-potassium (NPK) fertilizer, and of water alone, showed strong nutrient- and moderate water limitation in snow algae on the Harding Icefield because their abundance increased with the addition of each (Fig. 2a,c). Enrichment with NPK increased alga cell count significantly (negative-binomial generalized linear mixed model (GLMM), plot and block as random, treatment as fixed factor) and by nearly fourfold over controls (geometricmean response ratio: $\mathrm{G}_{\mathrm{E}: \mathrm{C}}=3.73 ; \mathrm{CI}_{95 \%}=2.4-5.7$ ), increasing in all 21 experimental blocks. On average, the addition of water alone also significantly increased alga counts $48 \%\left(\mathrm{G}_{\mathrm{W}: \mathrm{C}}=1.48\right.$; $\mathrm{CI}_{95 \%}=1.0-2.3$ ); 13 blocks showed an increase, supporting the hypothesis that liquid water is limiting. Addition of $\mathrm{HOCl}$ in a $10 \%$ bleach solution significantly reduced alga counts to $44 \%$ of control counts $\left(\mathrm{G}_{\mathrm{R}: \mathrm{C}}=0.44 ; \mathrm{CI}_{95 \%}=0.3-0.7\right) ; 17$ blocks showed reduction. Similar results held for other abundance measures (Supplementary Table 1). Treatment effects also manifested as timing of visible red snow, first detected from repeat photography (22 June) and in experimental plots (12 July). By 19 July, $>90 \%$ of nutrient-enriched plots, $50 \%$ of water and control plots, but only $10 \%$ of alga-reduction plots showed red snow. A single pulse of N-enrichment in-frame at the start of interval photography on the Eklutna Glacier also suggested a response of red-snow algae to nutrient enrichment, with earlier, more intensely red-coloured snow at and near the enrichment point (Supplementary Movie).

Previous field observations ${ }^{16,26}$ and in vitro microcosm nutrient additions $^{17,27}$ suggest that nutrient limitation in snow algae is study-dependent. For example, Lutz et $a .^{16}$ in a wide-ranging Arctic study found no correlation between alga abundance and nutrient concentrations in filtered red snow. In contrast, Fujii et al. $^{26}$ attributed Antarctic snow-alga distribution and abundance to allochthonous bird deposition of limiting nutrients. A field microcosm study on North American volcanoes ${ }^{27}$ found no NP-enrichment effect on snow-alga abundance, while a laboratory microcosm of Greenland cryoconite debris ${ }^{17}$ showed NPenrichment doubled both organic carbon and chlorophyll-a. Here, the response to NPK-enrichment in $2-\mathrm{m}^{2}$ plots exceeds the mean response of approximately $3.4 \times$ reported for pelagic phytoplankton in NP-enriched freshwater lakes ${ }^{28}$.

This experimental study tests for liquid-water limitation in snow algae, a critical first assumption of the feedback hypothesis; however, snow-alga's elevation range and life-cycle anticipate the observed increase in cell counts with water-only treatment. Drier than lowelevation snow, cold, high-elevation snow lacks alga colonization ${ }^{29}$. Classic studies of snow algae ${ }^{22}$ suggest that the appearance of liquid water and light in the spring initiates germination.

\section{Manipulating alga abundance manipulates melt}

The second assumption of the feedback hypothesis, that algae cause melt, was also supported (Supplementary Movie). Experimentally varying alga abundance correspondingly varied melt rate at the plot level following algae's appearance (22 June; Supplementary Fig. 4). Alga abundance predicted melt rate well as a square-root function of cell surface area (alga-melt model), suggesting a possible asymptote (Fig. 2b and Supplementary Table 1). Six weeks and three treatments into the 100-day experiment, melt rates were highest on average in enriched plots and lowest in reduced plots (Supplementary Fig. 4). Melt rate appeared decoupled from degree-day sum after 12 July, when red snow was visible. Including alga abundance or treatment as an interaction term significantly improved the 
a
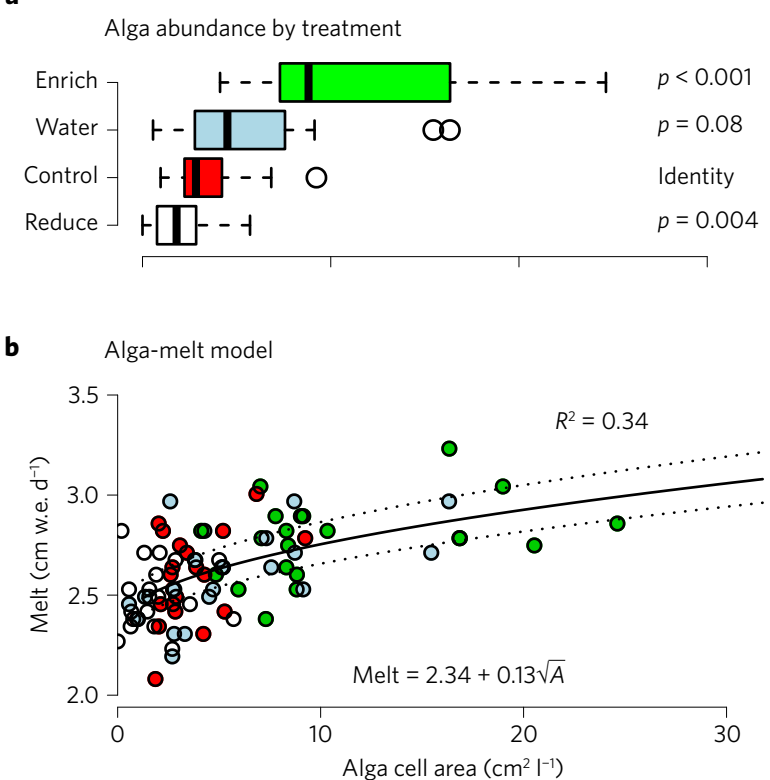

c Treatment effects by block

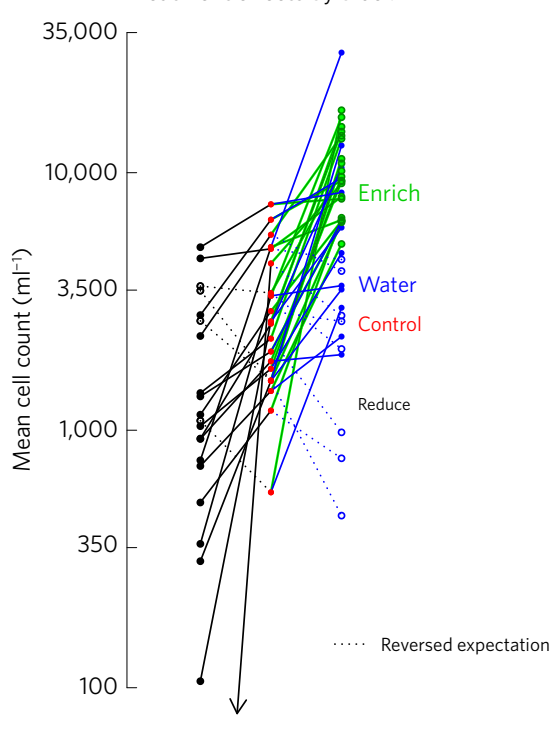

Figure 2 | Alga abundance increased by nutrient and water addition, decreased by $\mathrm{HOCl}$ addition with manipulated alga abundance determining snowmelt rate. a, Treatment effects on alga-cell surface area $\left(\mathrm{cm}^{2} \mathrm{I}^{-1}\right)$. Wald-test $P$ values $(\mathrm{df}=59$, one-tailed) of mean effects in mixed model of log-transformed abundance in margin. $\mathbf{b}$, Melt rate averaged from 13 to 27 July as snow-water-equivalent. Each bullet gives a treatment plot $(n=84)$. Melt rate as square root of alga abundance, $A$, indicated by solid curve, equation, and $R^{2}$. Dotted curves: $13-19$ and $20-27$ July models (Supplementary Table 2 ). c, Treatment effects on cell counts. Line segments link plot counts within experimental blocks; slope equal to response ratio (treatment:control count). Font size $($ Control $=1$ ) of text equals geometric-mean response ratio averaged across blocks. Black arrow points at zero count.

degree-day model after 12 July when comparing traditional degreeday melt models using a Likelihood Ratio Test (LRT: cell area: $p<0.001, \Delta \mathrm{AIC}=21.7$; treatment: $p=0.003, \Delta \mathrm{AIC}=7.9$ ); however, before 12 July, including treatment did not improve model performance $(p=0.51)$. Degree-day models, commonly applied in spatial calculations of snowmelt ${ }^{30}$, have not previously accounted for bioalbedo on snow.

Plots with experimentally increased algae also exposed bare ice earlier than reduction and control plots (Supplementary Movie). Twice as many enriched plots (28\% total), 50\% more water plots (20\%), and two-thirds as many reduced plots (10\%) as control plots (14\%) melted to ice or saturated firn by 10 August. Enriched plots were almost three times more likely than reduced plots to melt to bare ice or slush. By directly ablating clean snow (albedo $>0.75$ ) from glacial surfaces to reveal bare ice (albedo $<0.35^{16}$ ) that may not otherwise be exposed during the melt season, and by exposing ice sooner, algae indirectly amplify their melt effects ${ }^{16}$, and do so repeatedly due to their perennial life history.

We present three lines of evidence that experimental treatments manipulated melt through alga abundance and bioalbedo, rather than through physio-chemical processes. First, observed effects on melt occurred only after the appearance of red snow. There were no significant treatment effects on melt (Supplementary Fig. 4) until four treatment periods into the experiment. If physical processes related to treatments caused melt, then treatment effects would probably have occurred earlier. Second, alga-melt models (Supplementary Table 2) with and without treatment as a factor variable did not differ (LRT interaction $p=0.69$; additive $p=0.83$ ). This is a statistical result consistent with a negligible role for physical processes. Third, an enriched plot $\left(1.4 \times 10^{4}{\left.\text { cell } \mathrm{ml}^{-1}\right)}^{-1}\right.$ and a reduced plot (no cells detected) differed in melt rates as $\Delta H=10 \mathrm{~mm}$ w.e. $\mathrm{d}^{-1}$-where w.e. is water equivalent-well within the range predicted by a published physical model ${ }^{18}$ of bioalbedo $\left(8 \leq \Delta H \leq 15 \mathrm{~mm}\right.$ w.e. $\left.\mathrm{d}^{-1}\right)$. Most within-block values of $\Delta H$ were $<10$ mm w.e. $\mathrm{d}^{-1}$ (IQR 2-4 mm w.e. $\mathrm{d}^{-1}$; Supplementary Fig. 4). The generally smaller differences than theoretically predicted ${ }^{18}$ could be due to non-zero alga counts in reduction plots (Fig. 2c), an increase in snow-grain size, and so melt by HOCl, or both. Overall the results that suggest increased melt with increasing microbes occurred primarily through biologically driven radiative forcing, not physio-chemical change in grain size.

\section{Remote sensing of microbial impact}

The relationship between alga abundance and melt (alga-melt model; Fig. 2b) allowed estimation of snow algae's contribution to snowmelt across the Harding Icefield using Landsat- 8 satellite imagery. We sampled alga abundance and measured snow-surface reflectance using a field spectrometer (Fig. 3a) for comparison to modelled reflectance spectra ${ }^{3}$ for dust and black carbon (BC) at commonly observed concentrations (Fig. 3b,c). The field-measured spectrum of the lowest density alga sample $(7 \mathrm{ppm})$ was similar to the modelled spectrum of moderate density dust (172 ppm) with absorption $<650 \mathrm{~nm}$. Modelled BC reflectance spectra were uniform at these concentrations $(7-333 \mathrm{ppb})$. The alga reflectance spectra here generally agreed with previously published spectra for red-snow alga. The spectrum at $333 \mathrm{ppm}$ was similar in shape, but with lower values of reflectance, to a theoretical spectral albedo of snow with very high densities of algae ${ }^{18}$. The spectrum at $172 \mathrm{ppm}$ closely matched the field reflectance from a California sample ${ }^{9}$ of $2.1 \times 10^{4}$ cells $\mathrm{ml}^{-1}$ and less closely a red-snow sample from the Harding Icefield ${ }^{10}$, two studies that observed strong linear relationships between alga abundance and indices based on reflectance features in the $500-700 \mathrm{~nm}$ range. We, too, observed a strong linear relationship (NDI-alga model, Fig. $4 \mathrm{a}, R^{2}=0.93$ ) between field measures of alga abundance and a normalized snowdarkening index (NDI),

$$
\mathrm{NDI}=\left(R_{\text {red }}-R_{\text {green }}\right)\left(R_{\text {red }}+R_{\text {green }}\right)^{-1}
$$

where reflectance, $R_{i}$, is measured in the spectral regions corresponding to Landsat- 8 bands 4 (red: $636-673 \mathrm{~nm}$ ) and 3 (green: 533-590 nm). 
a

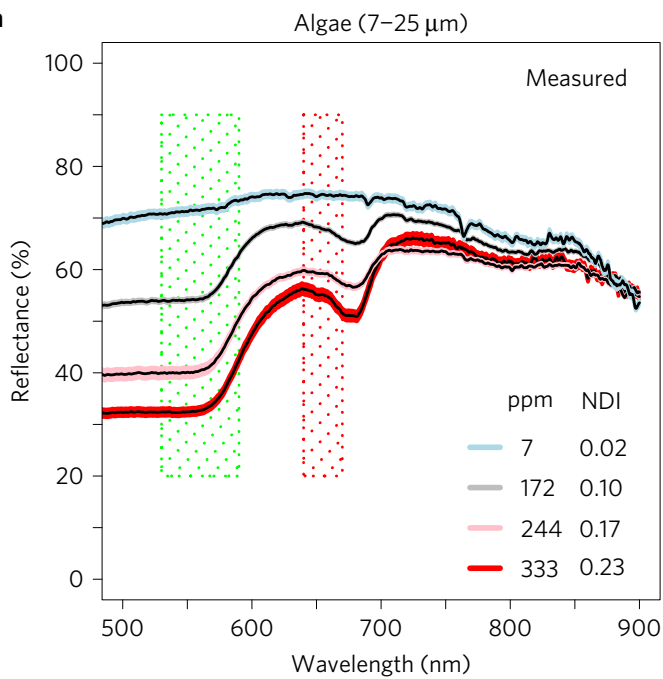

c

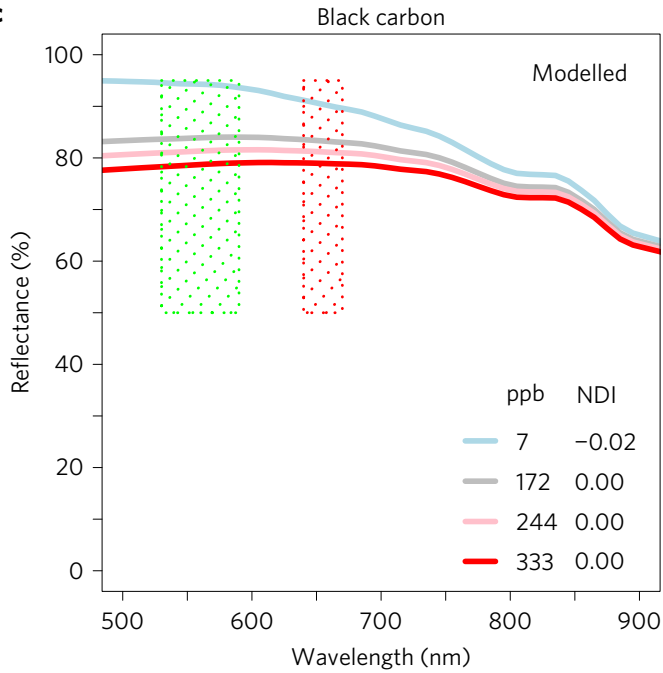

b

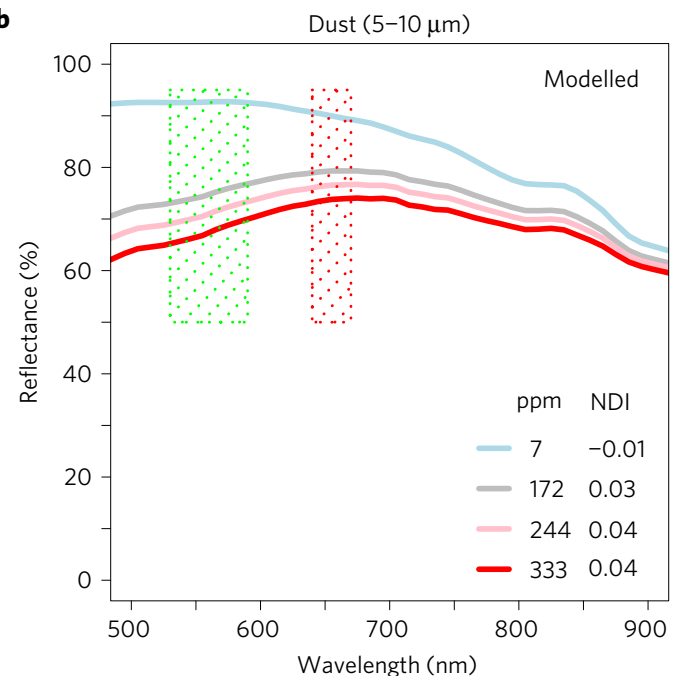

d

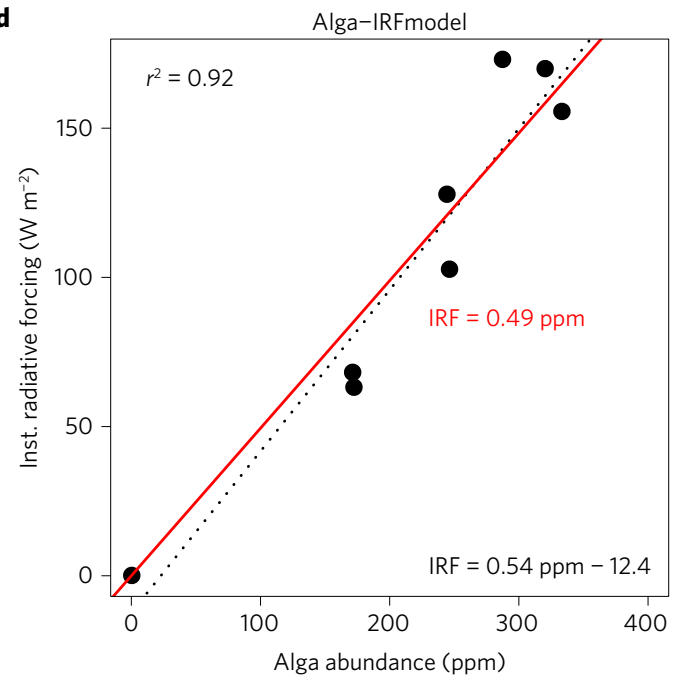

Figure 3 | Spectral reflectance varies by particle abundance and source. a, Mean reflectance spectra (mean \pm s.e.m., $n=10$ ) for snow samples of varying alga abundance. b,c, Modelled reflectance spectra for dust (b) and black carbon (uncoated in ppb) (c) using SNICAR. NDI $=\left(R_{\text {red }}-R_{\text {green }}\right)$ $\left(R_{\text {red }}+R_{\text {green }}\right)^{-1}$ for each curve. $\mathbf{d}$, Instantaneous radiative forcing by alga abundance. IRF $=\sum\left[\left(R_{\mathrm{A}}(\lambda)-R_{0}(\lambda)\right)\right] I R(\lambda) \Delta \lambda$ over $350 \leq \lambda \leq 850$, with $R_{\mathrm{A}}(\lambda)=$ reflection spectrum for alga abundance $A, R_{0}(\lambda)$ for alga-free snow and $\Delta \lambda=10 \mathrm{~nm}$. IR $(\lambda)=$ direct plus indirect solar irradiance normal to insolation at $60^{\circ} \mathrm{N} 150^{\circ} \mathrm{W}$ on 29 July 2013 at 11:09 local sidereal time. Red line is best fit through origin, black line is given by equation with $R^{2}$.

Because $R_{\text {red }} \leq R_{\text {green }}$ on clean ice and snow surfaces ${ }^{1}$, we interpreted NDI $\leq 0$ on cloud-free snow as a sufficient indicator for an absence of red-snow algae at the pixel scale. The NDI index developed here for algae (Fig. 3a) has been applied to measure mineral dust (Fig. 3b) on alpine snow ${ }^{31}$, and is insensitive to BC (Fig. 3c), which lacks algae's strong and dust's weak absorption peak $<600 \mathrm{~nm}$ (refs 18,23,31,32) (see Fig. 3a,c). NDI is more sensitive to alga abundance than equivalently common particle concentrations: at $172-333 \mathrm{ppm}$ NDI $>0.10$ for algae but NDI $<0.05$ for dust and NDI $=0$ for $\mathrm{BC}$ at $172-333 \mathrm{ppb}$. We did not attempt mixture modelling of algae, dust, and BC using NDI, but suggest this as an avenue for further study, particularly regarding dust particles that vary by colour. Here, four lines of evidence suggest NDI measured primarily algae on the Landsat- 8 images of the Harding Icefield during the 2013 melt season used in this study: no large fires or volcanic eruptions occurred nearby; the maritime icefield is distant from dust and soot sources; the maritime icefield is subject primarily to coastal, windward onshore winds and continental, leeward downglacier winds; and we found good visual agreement between a GPS track and satellite-predicted alga abundance on a Landsat-8 scene captured three days before we surveyed an isolated 1.25 ha dark red-snow patch on the icefield's surface with a sub-metre GPS (Fig. 4b). Nevertheless, it is most likely that the spectra in Fig. 3a represent a mixture of algae, dust, BC, and other substances; however, at this point we have no estimates for those values.

We present a landscape estimate of snowmelt due directly to snow algae. Pixels with NDI $\leq 0$ were omitted and those with NDI $>0$ (red-snow pixels) used to algebraically compose the alga-melt model (Fig. 2b) with the NDI-alga model (Fig. 4a), yielding snowmelt due to algae. On a cloud-free, unsaturated Landsat- 8 scene (29 July 2013) we spatially mapped total snowmelt in red-snow pixel- $i$ as $T_{i}=2.34+4.95\left(\mathrm{NDI}_{\mathrm{i}}\right)^{0.5}$. With algae absent $(A=0)$ the algamelt model yields $2.34 \mathrm{~cm}$ w.e. $\mathrm{d}^{-1}$, so snowmelt in pixel $-i$ due to microbes is $M_{i}=T_{i}-2.34=4.95\left(\mathrm{NDI}_{\mathrm{i}}\right)^{0.5}$. Summing across redsnow pixels gives snowmelt due to microbes, $M$, and total snowmelt, $T$, with the percentage increase due to algae over algae-free snow as $100^{*} M /(T-M)$.

Based on the Landsat-8 image from 29 July 2013 (Fig. 4c), redsnow pixels covered over a third $\left(661 \mathrm{~km}^{2}\right)$ of the icefield's total area. Based on this image, snow microbes generated $M=3.2 \mathrm{Gl} \mathrm{d}^{-1}$ (prediction interval, $\mathrm{PI}_{95 \%}$ : $0.8-5.7 \mathrm{Gl} \mathrm{d}^{-1}$ ), $17 \%$ of the total $T=18.7 \mathrm{Gl} \mathrm{d}^{-1}\left(\mathrm{PI}_{95 \%}: 16.2-21.2 \mathrm{Gl} \mathrm{d}^{-1}\right)$ from the $661 \mathrm{~km}^{2}$ area. 


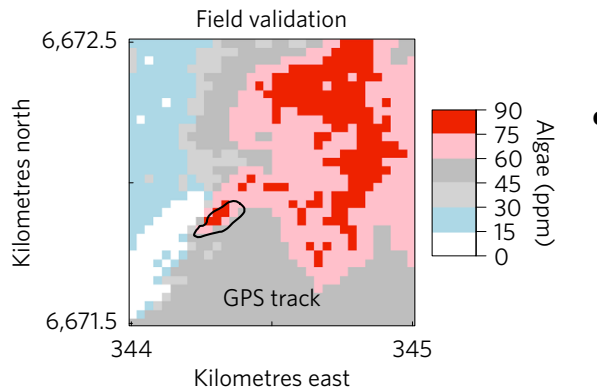

a

NDI-alga model
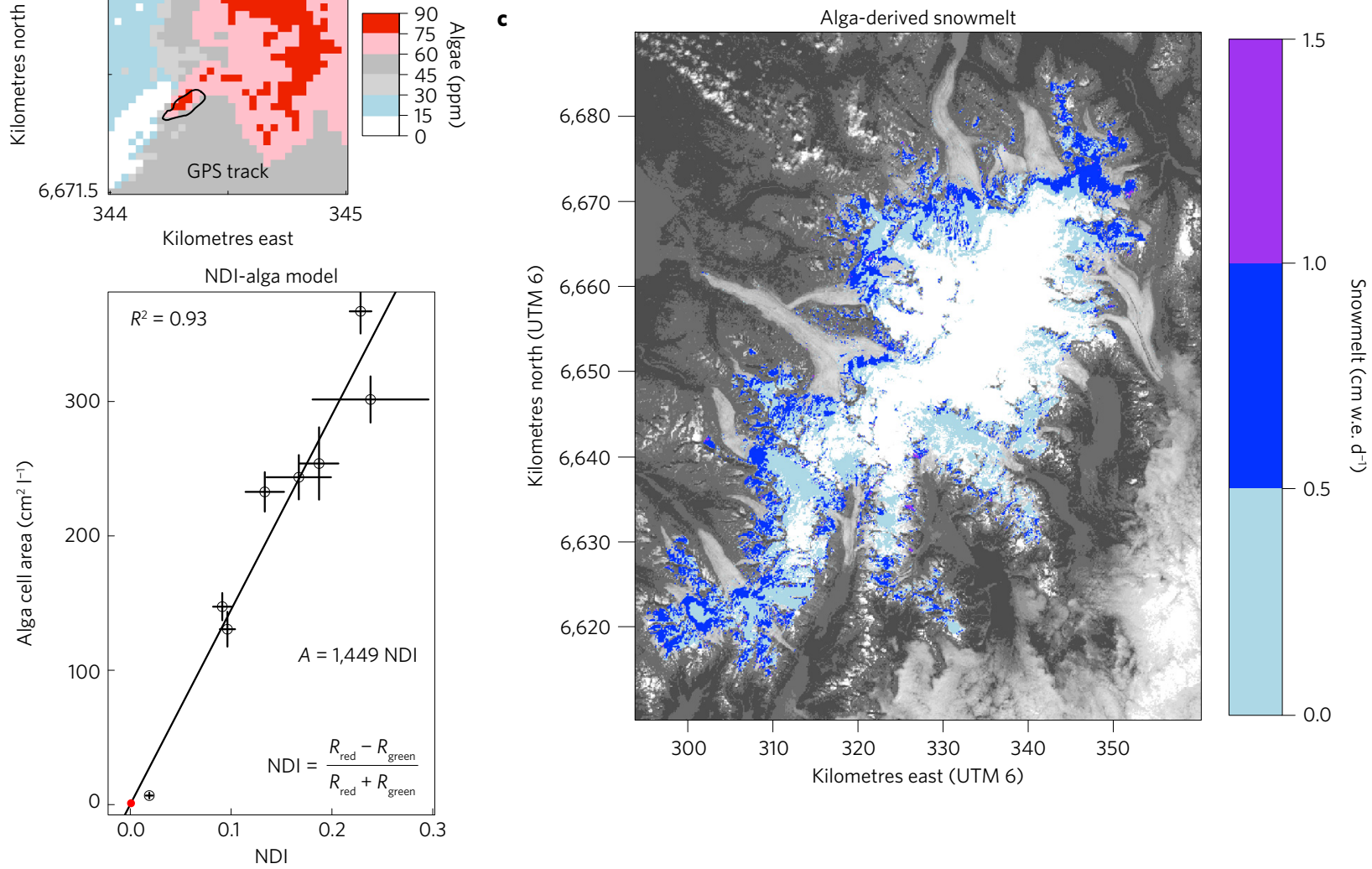

Figure 4 | Microbes drive snowmelt on a large Alaskan icefield. a, Snow-alga abundance versus NDI from field measurements of reflectance. Line is best fit with $R^{2}$. Error bars are \pm 1 s.e.m. b, Alga abundance mapped from NDI (NDI-alga ppm model; Supplementary Table 1) for 14 August 2013 Landsat-8 scene. Black outline indicates 1.25 ha red-snow patch traversed with GPS on 17 August 2013. White pixels are algae-free snow or ice (NDI $\leq 0$ ).

c, Estimated snowmelt on Harding Icefield due to snow algae on 29 July 2013. Pixels with NDI $\leq 0$ (and non-icefield snow) shown as composite Landsat-8 image. Cloud cover obscures the Gulf of Alaska in southeast corner of image.

Expressed as a percentage increase of snowmelt in the absence of snow algae, bioalbedo increased melt $21 \%$, an empirical estimate within the lower range of modelled predictions ${ }^{18}(20-40 \%)$ for bioalbedo on a snow-covered Greenland glacier. Additional indirect effects (for example, unveiling ice) are not included in this single day estimate. Musilova et al. ${ }^{17}$ calculated that $5 \%$ of the Greenland ice sheet's annual meltwater can be attributed to microbes dwelling in cryoconite. In general, microbial contribution to discharge will depend on the porosity of the glacier and its hypsometry, scaling with the length of the glacier's equilibrium-line altitude contour (snow algae's primary habitat ${ }^{21,29}$ ) and the cosecant of terrain slope there.

High albedo of snow-covered glaciers and ice sheets diminishes solar forcing ${ }^{2-4}$. Thus, red-snow algae could affect climate by reducing surface albedo. How great an effect can be assessed as a first approximation by calculating instantaneous radiative forcing (IRF). We calculated IRF using modelled irradiance and fieldmeasured reflectance values (Fig. 3a) sampled simultaneously with alga abundance. IRF was modelled as in refs 4,31 for each of seven alga densities (172-333 ppm) by subtracting each spectrum's wavelength-specific reflectance value from that observed for algae at $7 \mathrm{ppm}$ (indistinguishable from approximately $170 \mathrm{ppm}$ of dust; Fig. 3). Regressing IRF on alga abundance (alga-IRF model, Fig. $3 \mathrm{~d}, R^{2}=0.92$ ) predicted IRF across the Harding Icefield (Supplementary Fig. 5) with the Landsat-8 scene used for snowmelt by composing the alga-IRF model (Fig. 3d) with the NDI-ppm abundance model (Supplementary Table 1). The area-averaged IRF was $21.6 \mathrm{~W} \mathrm{~m}^{-2}\left(\mathrm{sd}=5.9 \mathrm{~W} \mathrm{~m}^{-2}\right)$, with a maximum $\left(87.9 \mathrm{~W} \mathrm{~m}^{-2}\right)$, similar to instantaneous radiative forcing values for large-scale dust events ${ }^{4,31}$. Multiplying melt rate $\left(\mathrm{PI}_{95 \%} 0.38-0.52 \mathrm{~cm} \mathrm{~d}^{-1}\right)$ due to algae by pixel area and latent heat of fusion $\left(334 \mathrm{Jg}^{-1}\right)$ suggested a daily-averaged radiative forcing $\mathrm{PI}_{95 \%}$ of $14.7-20.1 \mathrm{~W} \mathrm{~m}^{-2}$, near to but less than the area-averaged value of IRF $\left(21.6 \pm 5.9 \mathrm{~W} \mathrm{~m}^{-2}\right)$.

\section{Implications for high-latitude ice sheets}

This study highlights the substantial impact of red-snow communities on glacier melt at high elevations and latitudes. Experimental results presented here, together with previous correlative observations $^{8-16}$, laboratory experiments ${ }^{17}$, and theoretical calculations ${ }^{18}$, provide a compelling case for the magnitude of the glacier microbiome's effect on hydrology and climate. Snow algae amplify their albedo reduction through life history, population growth, dispersal, and physiology. They probably evolved under natural selection to actively melt snow, thereby generating needed liquid in a frozen environment. Snow algae contrast with episodic deposition of non-living particulates, which sink into the snowpack if hydrophilic or non-polar, and remain atop a single season's melting snowpack if hydrophobic ${ }^{33,34}$. Because algae remain on the surface over much of the melt season and perennially resurface across melt seasons, they compound their effects over time. Like arctic shrubs ${ }^{35}$, high-latitude microbes potentially drive a warming climate feedback if their radiative forcing at the regional scale increases the extent of near-freezing snowpack, their primary habitat. Given an upward-elevation shift with warming, algae will increase most rapidly across flat, snowcovered topography, such as Greenlandic and Antarctic ice sheets, regions with critical albedo effects on global climate ${ }^{2,3,36}$. Worldwide 
ash from biomass burning ${ }^{37}$ and dust from agricultural regions ${ }^{38}$ are increasingly deposited on these high-latitude ice sheets. This airborne nutrient input, together with growing meltwater availability $^{39}$, will certainly increase the glacier microbiome's impact on polar albedo. Climate and melt models that ignore the ecology of microbial radiative forcing risk underestimating rates of warming and consequent sea level rise.

\section{Methods}

Methods, including statements of data availability and any associated accession codes and references, are available in the online version of this paper.

\section{Received 10 March 2017; accepted 16 August 2017; published online 18 September 2017}

\section{References}

1. Wiscombe, W. J. \& Warren, S. G. A model for the spectral albedo of snow. I: Pure snow. J. Atmos. Sci. 37, 2712-2733 (1980).

2. Box, J. et al. Greenland ice sheet albedo feedback: thermodynamics and atmospheric drivers. Crysophere 6, 821-839 (2012).

3. Flanner, M. G., Zender, C. S., Randerson, J. T. \& Rasch, P. J. Present-day climate forcing and response from black carbon in snow. J. Geophys. Res. 112, D11202 (2007).

4. Bryant, A. C., Painter, T. H., Deems, J. S. \& Bender, S. M. Impact of dust radiative forcing in snow on accuracy of operational runoff prediction in the Upper Colorado River Basin. Geophys. Res. Lett. 40, 3945-3949 (2013).

5. Hood, E. et al. Glaciers as a source of ancient and labile organic matter to the marine environment. Nature 462, 1044-1047 (2009).

6. Musilova, M. et al. Microbially driven export of labile organic carbon from the Greenland ice sheet. Nat. Geosci. 10, 360-365 (2017).

7. Kohshima, S., Seko, K. \& Yoshimura, Y. In Snow and Glacier Hydrology 309-316 (Publication no. 218, IAHS, 1993).

8. Thomas, W. H., Duval, B. \& Nevada, S. California, USA, snow algae: snow albedo changes, algal-bacterial interrelationships, and ultraviolet radiation effects. Arct. Alp. Res. 27, 389-399 (1995).

9. Painter, T. H. et al. Detection and quantification of snow algae with an airborne imaging spectrometer. Appl. Environ. Microbiol. 67, 5267-5272 (2001).

10. Takeuchi, N., Dial, R. D., Kohshima, S., Segawa, T. \& Uetake, J. Spatial distribution and abundance of red snow algae on the Harding Icefield, Alaska derived from a satellite image. Geophys. Res. Lett. 33, L21502 (2006).

11. Yallop, M. L. et al. Photophysiology and albedo-changing potential of the ice algal community on the surface of the Greenland ice sheet. ISME J. $\mathbf{6}$, 2302-2313 (2012).

12. Takeuchi, N., Kohshima, S. \& Seko, K. Structure, formation, and darkening process of albedo-reducing material (cryoconite) on a Himalayan glacier: a granular algal mat growing on the glacier. Arct. Antarct. Alp. Res. 33, 115-122 (2001).

13. Stibal, M., Šabacká, M. \& Žárský, J. Biological processes on glacier and ice sheet surfaces. Nat. Geosci. 5, 771-774 (2012).

14. Lutz, S., Anesio, A. M., Villar, S. E. \& Benning, L. G. Variations of algal communities cause darkening of a Greenland glacier. FEMS Microbiol. Ecol. 89, 402-414 (2014).

15. Takeuchi, N. et al. The effect of impurities on the surface melt of a glacier in the Suntar-Khayata mountain range, Russian Siberia. Front. Earth Sci. 3, 82-92 (2015).

16. Lutz, S. et al. The biogeography of red snow microbiomes and their role in melting arctic glaciers. Nat. Commun. 7, 11968 (2016).

17. Musilova, M., Tranter, M., Bamber, J. L., Takeuchi, N. \& Anesio, A. M. Experimental evidence that microbial activity lowers the albedo of glaciers. Geochem. Perspect. Lett. 2, 106-116 (2016).

18. Cook, J. M., Hodson, A. J., Taggart, A. J., Mernild, S. H. \& Tranter, M. A predictive model for the spectral "bioalbedo" of snow. J. Geophys. Res. 122, 434-454 (2017).

19. Lutz, S., Anesio, A. M., Edwards, A. \& Benning, L. G. Linking microbial diversity and functionality of arctic glacial surface habitats. Environ Microbiol. 19, 551-565 (2016).
20. Hoham, R. W. \& Duval, B. Snow Ecology: An Interdisciplinary Examination of Snow-Covered Ecosystems 168-228 (Cambridge Univ. Press, 2001).

21. Anesio, A. M. \& Laybourn-Parry, J. Glaciers and ice sheets as a biome. Trends Ecol. Evol. 27, 219-225 (2011).

22. Hodson, A. et al. Glacial ecosystems. Ecol. Monogr. 78, 41-67 (2008).

23. Bidigare, R. et al. Evidence for a photoprotective for secondary carotenoids of snow algae. J. Phycol. 29, 427-434 (1993).

24. Remias, D., Lütz-Meindl, U. \& Lütz, C. Photosynthesis, pigments and ultrastructure of the alpine snow alga Chlamydomonas nivalis. Eur. J. Phycol. 40, 259-268 (2005).

25. VanLooy, J., Foster, R. \& Ford, A. Accelerating thinning of Kenai Peninsula glaciers, Alaska. J. Glaciol. 44, 570-582 (1998).

26. Fujii, M. et al. Microbial community structure, pigment composition, and nitrogen source of red snow in Antarctica. Microbial Ecol. 59, 466-475 (2010).

27. Hamilton, T. L. \& Havig, J. Primary productivity of snow algae communities on stratovolcanoes of the Pacific Northwest. Geobiology 15, 280-295 (2017).

28. Elser, J. J. et al. Global analysis of nitrogen and phosphorus limitation of primary producers in freshwater, marine and terrestrial ecosystems. Ecol. Lett. 10, 1135-1142 (2007)

29. Takeuchi, N. The altitudinal distribution of snow algae on an Alaska glacier (Gulkana Glacier in the Alaska Range). Hydrol. Process. 15, 3447-3459 (2001).

30. Hock, R. Temperature index melt modelling in mountain areas. J. Hydrol. 282, 104-111 (2003).

31. Di Mauro, B. et al. Mineral dust impact on snow radiative properties in the European Alps combining ground, UAV, and satellite observations. J. Geophys. Res. 120, 6080-6097 (2015).

32. Peltoniemi, J. I. et al. Soot on Snow experiment: bidirectional reflectance factor measurements of contaminated snow. Cryosphere 9, 2323-2337 (2015).

33. Conway, H., Gades, A. \& Raymond, C. F. Albedo of dirty snow during conditions of melt. Wat. Resour. Res. 32, 1713-1718 (1996).

34. Doherty, S. J., Warren, S. G., Grenfell, T. C., Clarke, A. D. \& Brandt, R. E. Light-absorbing impurities in Arctic snow. Atmos. Chem. Phys. 10, 11647-11680 (2010).

35. Sturm, M. et al. 2001: Snow-shrub interactions in Arctic tundra: a hypothesis with climatic implications. J. Clim. 14, 336-344 (2001).

36. IPCC Climate Change 2014: Synthesis Report (eds Core Writing Team, Pachauri, R. K. \& Meyer, L. A.) (Cambridge Univ. Press, 2014).

37. Keegan, K. M., Albert, M. R., McConnell, J. R. \& Baker, I. Climate change and forest fires synergistically drive widespread melt events of the Greenland ice sheet. Proc. Natl Acad. Sci. USA 111, 7964-7967 (2014).

38. Quinton, J. N., Govers, G., Van Oost, K. \& Bardgett, R. D. The impact of agricultural soil erosion on biogeochemical cycling. Nat. Geosci. 3, 311-314 (2010).

39. Harper, J., Humphrey, N., Pfeffer, W. T., Brown, J. \& Fettweis, X. Greenland ice-sheet contribution to sea-level rise buffered by meltwater storage in firn. Nature 491, 240-243 (2012).

\section{Acknowledgements}

C. McNeil, T. Tumulo, A. Meyerhofer, K. Loan, J. Geck, T. Golden and C. Tobin assisted, and D. Kurtz and the National Park Service permitted the research. NASA Alaska Space Grant funded G.Q.G. and R.J.D.; National Institute for Water Resources funded R.J.D. and M.G.L.; Anchorage Municipal Light and Power and Anchorage Water and Wastewater Utility funded M.G.L.

\section{Author contributions}

R.J.D. conceived and coordinated the project. G.Q.G. and R.J.D. designed ecology studies. G.Q.G. and M.G.L. performed glaciology. A.B.B., G.Q.G. and R.J.D. performed spectrometry. G.Q.G. and R.J.D. performed remote sensing. G.Q.G., M.G.L., and R.J.D. performed fieldwork. G.Q.G. performed laboratory counts. G.Q.G. and R.J.D. performed statistical modelling. R.J.D. wrote the paper with input from all.

\section{Additional information}

Supplementary information is available in the online version of the paper. Reprints and permissions information is available online at www.nature.com/reprints. Publisher's note: Springer Nature remains neutral with regard to jurisdictional claims in published maps and institutional affiliations. Correspondence and requests for materials should be addressed to R.J.D.

\section{Competing financial interests}

The authors declare no competing financial interests. 


\section{Methods}

Melt predictors and the emergence of red snow. Standard variables used for mass-balance studies ${ }^{40}$ on glaciers (for example, temperature, snow depth, depth-specific density, incoming and outgoing solar radiation) and interval photography of snow surfaces were collected from south-central Alaska's Harding Icefield on the Kenai Peninsula and the Eklutna Glacier in the Chugach Mountains (Supplementary Fig. 1). The Harding Icefield has been the site of both previous mass-balance ${ }^{25}$ and glacial biota studies ${ }^{10,41}$. We supplemented data from an automated weather station (AWS; RAWS Harding Icefield station http://www.raws.dri.edu/cgi-bin/rawMAIN.pl?akAHAR) $210 \mathrm{~m}$ above and $<3 \mathrm{~km}$ distant from our experimental study site $\left(60.156029^{\circ} \mathrm{N} 149.794006^{\circ} \mathrm{W}\right)$ with three temperature sensors (Onset, model HOBO Pendant datalogger in radiation shield) maintained $2 \mathrm{~m}$ above the snow surface at the vertices of the experimental study site (Supplementary Fig. 1) from 2 May to 10 August 2014. Positive degree-day $\left(>0{ }^{\circ} \mathrm{C}\right)$ sum was spatially modelled across the study site through a polynomial interpolation (ArcGIS, vers. 10.2) using temperature data collected from the vertices. Interval photography documented phenology of red snow. The alpine Eklutna Glacier has undergone mass-balance study since $2008^{42}$. An AWS on the glacier surface near the mass-balance equilibrium-line elevation (1,391 $\mathrm{m}$ asl) sampled melt variables hourly (2 May-20 August 2014). The AWS variables included incoming and outgoing radiation (290-3,000 nm; Hukseflux, model LP02L), liquid precipitation (Campbell Scientific, model TE525), cumulative snow/ice surface lowering (Motion Concepts, model Sonic Ranger SR50a), and temperature (Onset, model HOBO Pendant temperature). Broadband albedo was computed as the ratio of incoming and outgoing shortwave radiation during daylight hours. Hourly photography (Supplementary Movie) from a digital camera (Wingscapes, model BirdCamPro) located $1.5 \mathrm{~m}$ above the glacier surface at the AWS recorded the glacier surface. Oblique photo-interpretation was based on the presence of red snow and the pooling of supraglacial water (Fig. 1). Still photographs were assembled together as video with night-time images removed. Location of a N-rich solution deposited the day photography began occurs as yellow-coloured snow at the low centre of the first frame (Supplementary Movie).

Snowmelt was calculated as the observed change in snow thickness converted to water equivalent ( $\mathrm{cm}$ w.e.) based on density observations from snow profiles. Snowmelt $\left(\mathrm{cm}\right.$ w.e. $\left.\mathrm{d}^{-1}\right)$ over a given time interval was estimated by integrating depth-specific density $\rho(x)$ over depth, $x$, as melt $=\omega=\int_{z}^{z-\Delta} \rho(x) \mathrm{d} x$, where $z$ and $z-\Delta$ were the snow depths at time 1 and time 2, and $\Delta$ was the difference in snow depth at time 1 and time 2. On the Eklutna Glacier, difference in depth, $\Delta$, was calculated as the difference between sonic ranger measurements; on the Harding Icefield, as the difference between ablation cable length measurements We measured depth-specific snow density (ref. 40), $\rho(x)$ across depth $x(\mathrm{~cm})$ to old summer surface, at intervals $\Delta x \leq 25 \mathrm{~cm}$ (depending on snowpack heterogeneity). Depth-specific density, $\rho(x)$, was interpolated as piecewise linear across $x$ for snow-pit profiles at the Eklutna Glacier AWS on 2 May and 17 May 2014 and at the Harding Icefield (Supplementary Fig. 2) study site (1,075 m asl) on 17 May $\left(x_{\max }=3.8 \mathrm{~m}\right), 29$ June $\left(x_{\max }=2.3 \mathrm{~m}\right)$ and 27 July $\left(x_{\max }=0.8 \mathrm{~m}\right)$. Because daily measures of the three variables used to predict melt (that is, albedo, temperature, degree-day sum) are strongly correlated, we extracted the first principal component (PC1) of melt variables on the Eklutna Glacier using PCA. We then correlated daily melt on PC1 to estimate the strength of the relationship between variability in melt rate and the predictor variables.

Snow-algae manipulation and melt experiment. We executed a replicated $(21$ blocks $\times 4$ plots block ${ }^{-1}=84$ plots total), manipulative field experiment to quantitatively measure the impact of snow algae on snowmelt (2 May-10 August 2014) over a 97 ha portion of the NE Harding Icefield (Supplementary Fig. 1). Each of the experimental blocks (150-250 $\mathrm{m}$ apart) included four circular plots $\left(2 \mathrm{~m}^{2}\right)$, 3-4 $\mathrm{m}$ apart. Each plot in a block received a different treatment (except controls) and an ablation measurement on 17 May (day 0), 11 June (25 days following), 29 June (18 days following), 13 July (14 days following), 19 July (no treatments applied, 7 days following), and 27 July (14 days following), with a final ablation measure on 10 August 2014 (14 days following). Each block's treatments consisted of aerosol application of $250 \mathrm{ml}$ liquid per plot to: increase algae via fertilization with 5.6 $\mathrm{gl}^{-1}$ Scotts Super Bloom (12-55-6) as 9\% ammoniacal nitrogen, 3\% urea, $55 \% \mathrm{P}_{2} \mathrm{O}_{5}$, and $6 \% \mathrm{~K}_{2} \mathrm{OH}$ commercial fertilizer; increase algae via addition of water alone; decrease algae via $10 \%$ bleach ( $\mathrm{HOCl}$ ) solution. In addition, each block had an unmanipulated control plot. Treatment block locations (Supplementary Fig. 1) were recorded at sub-metre accuracy (Trimble, model GeoXH 2008 series GPS) on 20 August (1,074- 1,117 $\mathrm{m}$ asl; mean elevation 1,100 $\mathrm{m}$ asl).

We sampled snow-alga abundance in all plots on 19 July. We investigated the predictive ability of melt using three metrics of alga abundance: density of cell counts, density of cell surface area, and density of cell volume. Cell volume has been used in previous studies ${ }^{10,16,18}$. Four $10 \mathrm{ml}$ surface snow sub-samples were combined as a single sample per plot, melted and preserved in 3-6\% formalin under ambient field conditions. Abundance metrics were estimated from 10-mega-pixel micrographs (14-23 images plot $^{-1}$ ) of algae within a $1 \mathrm{ml}$
Sedgewick-Rafter counting chamber viewed through an optical microscope. Counts and diameters, $x$, of round cells $(5 \mu \mathrm{m}<$ diameter $<45 \mu \mathrm{m} ; \overline{\bar{x}}=11.3 \mu \mathrm{m}$, $\overline{\mathrm{sd}}=2.8 \mu \mathrm{m}, n=8,049$ cells) were recorded from $1.09 \mathrm{~mm}^{3}$ samples. We used ImageJ (version $1.49 \mathrm{n}$ ) to record cell count, $n$, mean diameter, $\bar{x}$, and standard deviation, $s d$, in $\mu \mathrm{m}$ from each micrograph. These statistics provided bootstrap estimates of individual cell diameters, $d$, circular surface area, $A=0.25 \pi d^{2}$, and spherical volume, $V=0.167 \pi d^{3}$. For each of the 1,670 micrographs, we generated 1,000 bootstrapped samples of $n$ diameters from a gamma distribution with scale $=\mathrm{sd}^{2} \bar{x}^{-1}$ and shape $=(\bar{x} \mathrm{sd})^{2}$. For each bootstrap sample, the cell area and volume of each of the $n$ cells were summed for the sample, then the 1,000 bootstrap samples were averaged and aggregated by plot. Some samples included cryoconite that masked uncounted cells. Oval-shaped cells were rare and excluded from counts. Abundance metrics were scaled as count density (cells $\mathrm{ml}^{-1}$ ), cell surface area density $\left(\mathrm{cm}^{2} \mathrm{l}^{-1}\right)$, and density of cell volume (ppm).

Particle abundance and spectral reflectance. We compared spectral reflectance of red-snow patches to the alga abundance of each snow patch by measuring reflectance with a portable spectrometer and sampling alga abundance as described above for the manipulative experiment. Square plots of snow $\left(10 \mathrm{~cm}^{2} ; n=8\right)$ on the Snowbird Glacier $\left(61.85^{\circ} \mathrm{N}, 149.21^{\circ} \mathrm{W}\right)$ were selected from a range of uniformly white to red-coloured snow from 19:30-21:30 AK DST on 17 August 2014 (=03:30-05:30 UTC 18 August $2014=18: 30-20: 30$ sidereal time) giving a solar zenith angle of $82^{\circ}-95^{\circ}$ under clear sky and diffuse sun. A portable spectrometer (Stellarnet, Greenwave model), calibrated at 400-1,050 nm, provided measures of surface reflectance. Calibration with a white standard ( $>97 \%$ reflectance) preceded measurements of 8-10 spectral samples $15-20 \mathrm{~cm}$ above $1.5 \mathrm{~cm}^{2}$ of snow surface. Immediately following spectral measurements, four $10 \mathrm{ml}$ surface snow samples were collected and combined, then cells counted $\left(n=20\right.$ counts sample $\left.{ }^{-1}\right)$ as above for the manipulation experiment. We used the date, time, and location of the reflectance measurements to find solar zenith angle from a solar insolation (ref. 43) calculator at PV Lighthouse website (https://www.pvlighthouse.com.au). The solar angle was low enough to use diffuse incident radiation in SNICAR models ${ }^{3}$ of particulates as black carbon (BC) and dust reflectance spectra (http://snow.engin.umich.edu). Details of parameters for SNICAR are indirect incident radiation, $1,000 \mu \mathrm{m}$ snow-grain radius, $3 \mathrm{~m}$ snowpack, $500 \mathrm{~kg} \mathrm{~m}^{-3}$ density, 0.3 visible and 0.7 NIR underlying albedo, uncoated $\mathrm{BC}$ with $\mathrm{MAC}$ scaling factor $=$ $1.0,5-10 \mu \mathrm{m}$ dust particles with 'Surface spectral distribution' set to 'Mid-latitude winter, clear-sky'; 'Greenland summit, clear-sky' gave similar results.

Instantaneous radiative forcing (IRF) for spectrometer measures of snow with algae was calculated as a finite sum approximating the integral

$$
\operatorname{IRF}=\int_{350}^{850}\left[R_{\mathrm{s}}(\lambda)-R_{\mathrm{p}}(\lambda)\right] I(\lambda) \mathrm{d} \lambda \approx \sum_{\lambda=350}^{850} 10\left[R_{i}(\lambda)-R_{7}(\lambda)\right] I(\lambda)
$$

where the difference in wavelength-specific reflectance between clean snow, $R_{\mathrm{s}}(\lambda)$, and snow with particulates, $R_{\mathrm{p}}(\lambda)$, is weighted by global irradiance, $I(\lambda)$, and multiplied by the wavelength interval in the sum (here $10 \mathrm{~nm}$, from 350 to $850 \mathrm{~nm}$ ). $R_{7}(\lambda)$ was the reflectance spectrum from the field spectrometer for algae at $7 \mathrm{ppm}$ and $R_{i}(\lambda)$ was the reflectance spectra for algae at $i=$ ppm (Fig. 3a). We downloaded $I(\lambda)$ for $\mathrm{N} 60^{\circ} \mathrm{E}-150^{\circ}$ on 29 July 2014 at 13:10 AK DST (converted to local sidereal time) using https://www.pvlighthouse.com.au. This instantaneous irradiance spectrum was used to calculate IRF for each of the seven samples of alga abundance. A linear function fits the relationship of IRF regressed on alga abundance well (Supplementary Fig. 6) and is referred to as the 'alga-IRF model'.

Statistical analyses. Statistical and spatial modelling was undertaken with $\mathrm{R}$ $(v$. 3.3.2) and included packages lmer, lme4, nlme, lmtest, raster, and rgdal. Analysis of treatment effects used linear (LMM) and generalized linear mixed-effects (GLMM) models with control plots as reference in an effects parameterization of a balanced design of three treatment plots and a control (four levels of a fixed factor) per random block ( $m=21$ blocks; $n=84$ plots total). We tested treatment effect on raw cell counts, cell density, cell area density, and cell volume density (ppm), the latter frequently used in the literature. We also used GLMMs with plot (variable numbers of micrographs per plot) and block as random effects, treatment as a fixed factor, and micrograph cell count as a negative binomial and as a Poisson response variable. We chose the negative binomial because Poisson-regression residuals were overdispersed. Scaled alga abundance (counts $\mathrm{ml}^{-1}$, area $\mathrm{ml}^{-1}$ and volume $\mathrm{ml}^{-1}=\mathrm{ppm}$ ) was right-skewed with variance increasing with mean, so abundance was log or square root transformed for use in LMMs, establishing the effect of treatments on scaled abundance measures. Treatment effect on cell counts is reported as the geometric mean of the response ratio of treatment to control counts as in a review of enrichment experiments ${ }^{28} . P$ values compare treatment effects to control as one-tailed Wald tests, with $\alpha=0.05$ the critical value for significant deviation from statistical null hypotheses.

We investigated treatment effect on melt rate with three analyses. One analysis derived a function that could predict melt rate given alga abundance ('alga-melt 
model'). We used linear regression of melt rate from 12 to 27 July on square-root-transformed alga abundance (cell surface area in $\mathrm{cm}^{2} \mathrm{l}^{-1}$ ) sampled on 19 July with all $n=84$ plots and treatment as an additional independent variable. Second, because we anticipated that treatment effects on melt rate would differ by melt sub-season depending on algal presence (see Fig. 1a), we applied an LMM (block as random, treatment as fixed effect) to each of six time periods, with a Tukey HSD post hoc test when $\operatorname{Pr}\left(\mathrm{F}_{3,79}\right)<0.05$. In our third analysis, we parameterized a degree-day sum (DS) model for melt $(H)$ passing through the origin with alga abundance $(A)$ included as an interaction term, $H=\left(b_{0}+b_{1} A\right)$ DS. Phenomenological models apply thawing degree-day sum to predict glacial melt using temperature ${ }^{30,40}$. Our assumption of interaction imposes the following two conditions. First, if no days are above $0^{\circ} \mathrm{C}(D S=0)$ yet alga abundance is positive, then melt remains zero. Second, the effect of algae on snowmelt is to increase the degree-day factor, $b=b_{0}+b_{1} A$. We compared degree-day sum models with alga abundance (or treatment before June 22) to models without using Likelihood Ratio Tests (LRT). After we experimentally established an alga-melt effect, we determined the best form and variables of a predictive model among the scaled alga abundance measures and their various transformations, $f$, using simple linear regression to estimate melt, $H$ ( $\mathrm{cm}$ w.e. $\mathrm{d}^{-1}$ ), as a function, $f$, of abundance, $A$, as $H=s_{0}+s_{1} f(A)$, an 'alga-melt model'.

Spatial modelling. A previous study ${ }^{10}$ of snow algae on the Harding Icefield applied satellite remote sensing (SPOT) after sampling alga cell abundance and regressing it against field measures of spectral reflectance in the $600-700 \mathrm{~nm}$ range. In our study, after simultaneously measuring snow-alga abundance and reflectance values, $R$, we constructed two normalized-difference indices, NDI,

$$
\mathrm{NDI}=\left(R_{\text {red }}-R_{\text {green }}\right)\left(R_{\text {red }}+R_{\text {green }}\right)^{-1}
$$

where 'red' is Band 4 of Landsat-8 (636-673 nm) and 'green' is Band 3

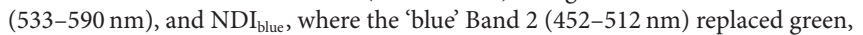

$$
\mathrm{NDI}_{\text {blue }}=\left(R_{\text {red }}-R_{\text {blue }}\right)\left(R_{\text {red }}+R_{\text {blue }}\right)^{-1}
$$

Astaxanthin absorbs ${ }^{44}$ in the $350-570 \mathrm{~nm}$ region (green and blue) and reflects $>600 \mathrm{~nm}$, supporting these band choices. Reflectance spectra, $R_{i}(\lambda)$, at wavelength $\lambda$ and alga abundance $i$ were recorded at $\Delta \lambda=0.5 \mathrm{~nm}$ intervals using a field spectrometer (see Particle abundance and spectral reflectance above). Reflectance values were averaged across each band and across samples for use in NDI. Alga abundance, $A$, regressed against NDI and $\mathrm{NDI}_{\text {blue }}$ in simple linear models provided the 'NDI-alga model', $A=c_{0}+c_{1}$ NDI, used to predict alga abundance given

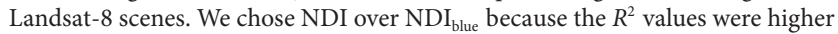
and the intercept was closer to zero with NDI. Among the three metrics of alga abundance, NDI predicted cell surface area best (Supplementary Table 1).

Note that if $R_{\text {red }}-R_{\text {green }} \leq 0$, when $R_{\text {red }}<R_{\text {green }}$, then NDI $\leq 0$. This occurs when algae are absent, and so pixel- $i$ with $\mathrm{NDI}_{\mathrm{i}} \leq 0$ was removed from further analysis, such as melt or IRF estimates across the Harding Icefield. Only pixels with NDI $>0$ ('red-snow' pixels) were used.

As a measure of validation of NDI for identifying algae from Landsat- 8 scenes, with a sub-metre GPS (Trimble, model GeoXH 2008) we outlined the boundaries of an isolated 1.25 ha, dark red-snow patch on the Harding Icefield at the south-west corner of the study area (Supplementary Fig. 1) on 17 August 2013. We compared the outline of this red-snow patch to red snow predicted from a Landsat-8 scene (LC80680182013226LGN00, collected 14 August 2013). The Landsat scene was transformed to NDI values, with NDI $\leq 0$ removed. Then we applied the NDI-alga (ppm) model to predict alga abundance (Supplementary Table 1) to generate alga abundance pixel by pixel and overlayed the GPS path.

We estimated snowmelt due to algae on the Harding Icefield for a single day as follows. A cloud-free, unsaturated Landsat-8 scene (LC80680182013210LGN01) of the Harding Icefield acquired at 21:09 GMT (11:09 local sidereal time) on 29 July 2013 was transformed to NDI values with NDI $\leq 0$ removed, leaving only red-snow pixels. Pixels with NDI $<0$ were removed because a negative NDI occurs if and only if reflectance in the green band surpasses reflectance in the red band $\left(R_{\text {red }}<R_{\text {green }}\right)$, which suggests red-snow algae are absent based on reflectance spectra of algae, dust, black carbon (Fig. 3) and clean snow. Each pixel $\mathrm{l}_{\mathrm{i}}$ with a positive NDI received a snow-alga abundance value, $A_{i}$, estimated with the NDI-alga model as $A_{i}=c_{1} \mathrm{NDI}_{i}$, where $c_{1}$ was estimated as the regression coefficient using least-squares linear regression through the origin. The predicted alga abundance in pixel $_{i}$ was then algebraically composed with the alga-melt model as per-pixel snowmelt rate, $H_{i}=s_{\mathrm{o}}+s_{1} f\left(A_{i}\right)=s_{\mathrm{o}}+s_{1} f\left(c_{1} N D I_{i}\right)$, where $i$ denotes the $i$ th pixel.

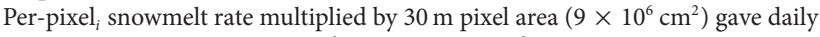
volume flux for each pixel $_{i}$ in $\mathrm{ml} \mathrm{d}^{-1}$, as $v_{i}=9 H_{i} \times 10^{6}$. The volume flux was then summed across all pixels on the Harding Icefield with non-zero NDI (that is, 'red-snow pixels' where algae were present) as an estimate of total icefield snowmelt, $T$, where algae were detected using NDI. We then set alga abundance equal to zero in the alga-melt model for each red-snow pixel as $H_{0}=s_{0}+s_{1} f(0)=s_{0}$, converted to volume flux $=9 s_{0} \times 10^{6}$, and summed across red-snow pixels to get the non-alga-derived snowmelt, $G$. The difference, $T-G$, gave alga-derived snowmelt on the day of imagery scaled to $\mathrm{Gl} \mathrm{d}^{-1}$ by multiplying by $10^{-12}$. The $95 \%$ prediction error was found as $T \pm \varepsilon$. If $N=$ the number of red-snow pixels, then total melt across the red-snow area was estimated as the sum over $i=1, \ldots, N$ pixels.

$$
T=9 \times 10^{-6} \sum^{N}\left(2.33+0.13 \sqrt{A}_{i}\right)
$$

with

$$
\varepsilon=9 \times 10^{-6}(1.96) \sum_{i}^{N} \sqrt{\mathrm{se}_{i}^{2}+\sigma^{2}}
$$

as the total prediction error, where for pixel $i$ the value $s e_{i}$ was pixeli's standard error of predicted melt and $\sigma$ was the standard deviation of residuals from the regression of melt on square root of algal area. Pixel values of expected melt were found using the predict.lm function in $\mathrm{R}$ applied to extracted pixel values of algal area, themselves found using NDI values.

We used a similar method of function composition to calculate IRF across the red-snow pixels (NDI $>0$ ) of the Harding Icefield at the day and time of the Landsat- 8 scene capture used for melt estimation. In this case, however, both functions were linear least squares. First we used the regression of alga abundance in ppm against NDI as an NDI-alga model, $\mathrm{ppm}=p_{\mathrm{o}}+p_{1} \mathrm{NDI}$, (Supplementary Table 1), then we used the regression of IRF against alga abundance through the origin as IRF $=g_{1}$ ppm ('alga-IRF model', Supplementary Fig. 5). In summary, given red-snow pixel $_{\mathrm{i}}$ with Landsat-scene value $\mathrm{NDI}_{\mathrm{i}}$, the pixel's instantaneous radiative forcing was $\mathrm{IRF}_{i}=g_{1} \mathrm{ppm}=g_{1} p_{\mathrm{o}}+g_{1} p_{1} \mathrm{NDI}_{\mathrm{i}}$.

In the case of IRF we did not calculate the total contribution to radiative forcing over time or over the icefield, but instead determined the statistical distribution of pixel values of IRF to compare to the heat of enthalpy needed to generate predicted melt on the Harding Icefield.

We checked the melt rate against instantaneous radiative forcing using the latent heat of fusion, $\Omega=334 \mathrm{~J} \mathrm{~g}^{-1}$. To estimate the total energy needed, $E_{H}$, to melt $H \mathrm{~cm}$ w.e. $\mathrm{d}^{-1}$ over $1 \mathrm{~m}^{2}$ (melt volume $=10^{4} \mathrm{Hg} \mathrm{m}^{-2}$ ), we multiplied $\Omega$ by melt volume per day to arrive at $E_{H}=3.34 \mathrm{H} \times 10^{6} \mathrm{~J} \mathrm{~d}^{-1}=38.7 \mathrm{H} \mathrm{W} \mathrm{m} \mathrm{W}^{-2}$ as an average over $24 \mathrm{~h}$ of high-latitude irradiance $\left(60^{\circ} \mathrm{N}, 29\right.$ July). The mean melt across the Harding Icefield's red-snow pixels was $\bar{H}=0.45 \mathrm{~cm}$ w.e. $\mathrm{d}^{-1}$ with $\mathrm{PI}_{95 \%}$ $0.38-0.52$, suggesting a daily-averaged radiative forcing $\mathrm{PI}_{95 \%}$ of $14.7-20.1 \mathrm{~W} \mathrm{~m}^{-2}$, near to but less than the area-averaged value of IRF $\left(21.6 \pm 5.9 \mathrm{~W} \mathrm{~m}^{-2}\right)$ found above by composing the alga-IRF model (Fig. 3d) with the NDI-ppm model (Supplementary Table 1). More generally, IRF calculated by composing NDI-alga ppm with alga-IRF models (that is, IRF $=637 \mathrm{NDI}+15$ in $\mathrm{W} \mathrm{m}^{-2}$ ) is greater than the power surface density required to generate meltwater calculated by composing NDI-alga with alga melt $\left(E_{H}=191.3 \sqrt{\mathrm{NDI}}\right.$ in $\left.\mathrm{W} \mathrm{m}^{-2}\right)$ : that is, if NDI $>0$, then $\mathrm{IRF}>E_{H}$ (Supplementary Proof).

Code availability. The code that supports the findings of this study is available from the corresponding author upon request.

Data availability. Landsat-8 images LC80680182013226LGN00 (Product identifier on Earth Explorer LC08_L1TP_068018_20130814_20170309_01_T1) and LC80680182013210LGN00 (Product identifier

LC08_L1TP_068018_20130729_20170309_01_T1) were downloaded from USGS Earth Explorer (https://earthexplorer.usgs.gov). Reflectance spectra for dust and black carbon were downloaded from SNICAR online

(http://snow.engin.umich.edu). Insolation data for satellite scene date, time, and location were downloaded from the PV Lighthouse website

(https://www.pvlighthouse.com.au) solar insolation calculator. Automated weather data on the Harding Icefield were downloaded from RAWS Harding Icefield (http://www.raws.dri.edu/cgi-bin/rawMAIN.pl?akAHAR). The data that support the findings of this study are available from the corresponding author upon request.

\section{References}

40. Hubbard, B. \& Glasser, N. F. Field Techniques in Glaciology and Glacial Geomorphology (John Wiley, 2005).

41. Dial, R. J. et al. The role of temperature in the distribution of the glacier ice worm Mesenchytraeus solifugus (Annelida: Oligochaeta: Enchytraeidae). Arct. Antarct. Alp. Res. 48, 199-211 (2016).

42. Sass, L. C., Loso, M. G., Geck, J., Thoms, E. E. \& McGrath, D. Geometry, mass balance and thinning at Eklutna Glacier, Alaska: an altitude-mass-balance feedback with implications for water resources. J. Glaciol. 63, 343-354 (2017).

43. Ricchiazzi, P., Yang, S. R., Gautier, C. \& Sowle, D. SBDART: a research and teaching software tool for plane-parallel radiative transfer in the Earth's atmosphere. Bull. Am. Meteorol. Soc. 79, 2101-2114 (1998).

44. Collins, A. M. et al. Carotenoid distribution in living cells of Haematococcus pluvialis (Chlorophyceae). PLoS ONE 6, e24302 (2011). 